\title{
Writing Professional Genres in a Second Language: Results from a Spanish University Clil Context
}

\author{
Maria Del Mar Sanchez Perez , Maria Sagrario Salaberri Ramiro \\ Department of Philology, University of Almeria, Almeria, Spain \\ *Corresponding author:spm727@ual.es
}

Received April 05, 2015; Revised April 12, 2015; Accepted April 17, 2015

\begin{abstract}
Bilingual educational programmes and projects have increased during the last few years and are currently being implemented in different Spanish universities through new teaching approaches such as CLIL (Content and Language Integrated Learning) or EMI (English-Medium Instruction). Research conducted at university level reveal that university students often have difficulty in performing the cognitive and discursive operations involved in the comprehension and production of written texts. These difficulties aggravate when this written performance is conducted in a non-native language, which is being increasingly demanded to university students participating in CLIL programmes. In Higher Education, both lecturers and students belong to certain communities of knowledge and practice, thus the second language needs to be acquired considering the different genre types used in different subjects as products connected to particular fields of knowledge. The present study analyses the written production of a professional genre type by Engineering university students in a second language (English) at a Spanish university. Results show the relationship between their academic performance (content achievement) and their linguistic awareness of the genre produced in a second language, being the higher marked texts (in terms of content performance) those which show a better writing (language) performance. These differences are more remarkable at a textual and discourse level. Fewer differences between higher and lower-marked texts are found at a sentence level.
\end{abstract}

Keywords: writing, professional genres, second language, university, engineering, CLIL

Cite This Article: Maria Del Mar Sanchez Perez, and Maria Sagrario Salaberri Ramiro, "Writing Professional Genres in a Second Language: Results from a Spanish University Clil Context.” American Journal of Educational Research, vol. 3, no. 5 (2015): 576-580. doi: 10.12691/education-3-5-7.

\section{Introduction}

The European Higher education System (EHEA) is undergoing a process of deep changes which include a continuous growth of interest and concern for the domain of foreign languages, mainly English. Many programs and projects related to bilingual teaching are being implemented in Europe and in many Spanish universities through different educational approaches such as the Content and Language Integrated Learning (CLIL). Some studies reveal that CLIL approaches do not place too much emphasis on activities aimed at producing written work as on other linguistic skills [1,2]. Moreover, research conducted at university level reveal that university students often have difficulty in performing the cognitive and discursive operations involved in the comprehension and production of written texts. However, written performance is considered a skill which should be enhanced, especially in higher education due to its importance in both educational and professional contexts.

The CLIL approach has been defined as a dual-focused educational approach in which an additional language is used for the learning and teaching of both content and language [3]. This approach is progressively being implemented in higher education [4].

Some studies reveal that the bilingual teaching approaches do not place too much emphasis on activities aimed at producing written work as on other linguistic skills [1,2]. Moreover, research conducted at university level reveal that university students often have difficulty in performing the cognitive and discursive operations involved in the comprehension and production of written texts. These difficulties aggravate when this written performance is conducted in a non-native language, which is being increasingly demanded to university students participating in CLIL programmes. In Higher Education, both lecturers and students belong to certain communities of knowledge and practice, thus the second language needs to be acquired considering the different genre types used in different subjects as products connected to particular fields of knowledge.

Some authors [5] define the CLIL educational approach as a shift from the linguistic contents into text genre elements. In light of the contributions of this author it can be said that the textual genre is the natural environment where the elements are used in specialized languages, providing the perfect backdrop for its natural use. In addition, students need to know how to use the elements of the genres in question properly. The awareness of the 
genres of each discipline helps lecturers to teach content without losing the skills of the academic L2 under consideration.

The purpose of this study is to analyze the written production of a professional genre type by Engineering university students in a second language at a Spanish university. Results show the relationship between their academic performance (content achievement) and their linguistic awareness of the genre produced in a L2 (language fluency).

\subsection{The Concept of Genre and the Implications for the Present Study}

The concept of genre was defined by [6], following the contributions of [7] as a specific communicative event, recognizable by the members of an academic or professional community that, apart from having one or more specific communicative objectives, has a protocolized structure. Basically, genres are defined according to the use of language in conventionalized communicative contexts [8]. They are intended to serve the purposes of the discourse community whose conventions tend to establish relatively stable structural forms.

At university level, it is reasonable to introduce a second language in classrooms with the purpose of teaching both content and language going beyond the grammar and syntax approach usually used in earlier educational levels. At this stage, both lecturers and students belong to certain communities of knowledge and practice, defined by [9] as a collection of people who engage on an ongoing basis in some common endeavour. The foreign language thus needs to be acquired considering the different genre types used in different subjects as products connected to particular fields of knowledge. Language thus needs to be understood as text and discourse, that is, the use of language beyond the sentence. The inclusion of genre awareness in teaching academic writing, especially in a foreign language, is considered to be an essential teaching tool [10]. [11] supports the idea that those individuals who master discourse skills obtain better academic results and are able to produce more complete and complex texts with an academic purpose. An explicit teaching of genres allows students to produce discursive frameworks in which organize the disciplinary content, while building and developing an identity as academic writers of a discipline in a foreign language [12].

\section{Context of the Study}

The present study was carried out at a Spanish university using the CLIL approach in some higher education courses under the framework of an official Plurilingualism Promotion Plan. The course under analysis is a 6-ECTS Chemistry course taught in English during the academic year 2012-2013 as part of the syllabus of the first academic year of the Degree in Agricultural Engineering. The course has been taught by two non-native-English-speaker lecturers and it was developed in the Chemistry laboratory, with a total amount of students of 25 (14 males and 9 females). All students were Spanish native speakers with an average age of 20. A specific assignment was provided to students at the beginning of each unit: they had to carry out the experiment assignment ("Report") and finally, a final lab report including all the steps and results obtained during the practice process had to be made and handed for assessment. Students were grouped into 3-member work teams thorough the whole course. Both the experiment assignments and the lab report writing had to be done jointly by the 3-member groups.

\subsection{Method}

In order to analyze the lab report written by the students, a standard checklist was designed both by the lecturer and the researcher so that the standard textual and linguistic features of these types of text could be determined. To do that, a total of 10 lab reports were analyzed and a set of common textual, meta discourse, lexico-semantic and morpho-syntactic features were defined as the general elements that a proper lab report should contain ${ }^{\mathbf{1}}$.

The textual and linguistic features proposed by [13] on macrostructure, moves and submoves have been followed in this study. Further to the textual (macrostructural) level described above, another level of study related to the text cohesion and coherence is essential for proper genre writing was considered. This corresponds to the metadiscourse level which focuses on consists of the presence of discourse markers that provides cohesion and coherence to the text. These markers have been defined as invariant linguistic units that do not exert a syntactic function in the context of the sentence, as they are marginal elements and have a matching task within the discourse: guiding the inferences performed in communication, according to their different morphosyntactic, semantic and pragmatic properties [14].

Further linguistic elements related to the concept of register, defined by [15] were added to the written production of this textual genre such as lexico-semantic and morpho-sintactic features. The lexicon of scientific language refers primarily to mechanisms, materials, tools, processes and methods, among others [16]. With regard to the lexico-semantic elements appearing in scientific reports we can highlight the use of technicisms, word formation (derivation and composition) and the use of abbreviation or acronyms. As for the morpho-syntactic elements it should be highlighted the abundance of nominalizations, long nominal sentences, impersonal forms, modal verbs and passive voice.

The checklist designed to analyze the written production of the students contained different levels from a multidimensional perspective: at a textual, discourse and sentence level. (A) text, (B) discourse, (C) morpho-syntax and (D) lexico-semantics.

\section{Results}

Three different the lab reports (R) were selected (R1, $\mathrm{R} 2$ and R3) among the three-member team groups in order

\footnotetext{
${ }^{1}$ A small-scale pilot study was conducted by the researchers prior to the use of the checklist for the present study in order to check its reliability. The checklist was handed to three colleagues from the Department who were asked to check whether the contents and the information were appropriate and understandable. Minor changes were performed after the review made by the participants in terms of lexicon and presentation of the information.
} 
to compare their performance. The first one (R1) corresponds to the lowest marked by the lecturer, the second one (R2) to a medium marked and the third one

(R3) to the highest marked.

Table 1. Parameters followed to design the guiding checklist of the lab report genre

\begin{tabular}{|c|c|c|c|}
\hline \multicolumn{4}{|c|}{ GENRE ANALYISIS } \\
\hline \multirow{9}{*}{$\begin{array}{l}\text { 1. Textual level } \\
\text { (Macrostructure) }\end{array}$} & \multirow{9}{*}{$\begin{array}{l}\text { Primary Structure } \\
\text { (SECTIONS) } \\
\text { and Secondary Structure } \\
\text { (Moves) }\end{array}$} & $\begin{array}{l}\text { SECTION } 1 . \\
\text { Report information }\end{array}$ & $\begin{array}{l}\text { Move 1: Presentation of the author's data, date of the experiment } \\
\text { and title. }\end{array}$ \\
\hline & & $\begin{array}{l}\text { SECTION 2. Introduction / } \\
\text { Purpose }\end{array}$ & $\begin{array}{l}\text { Move 2: Presentation of information related to the topic. } \\
\text { Move 3: Introduction of the problem or question to be solved in the } \\
\text { laboratory and hypothesis. } \\
\text { Move 4. Presentation of the objectives or purpose of the experiment. }\end{array}$ \\
\hline & & $\begin{array}{l}\text { SECTION } 3 . \\
\text { Materials }\end{array}$ & $\begin{array}{l}\text { Move 5: Description of materials and equipment used to conduct the } \\
\text { experiment. }\end{array}$ \\
\hline & & $\begin{array}{l}\text { SECTION 4. Methods/ } \\
\text { Procedures }\end{array}$ & $\begin{array}{l}\text { Move 6: Description of the steps completed to develop the } \\
\text { experiment. }\end{array}$ \\
\hline & & $\begin{array}{l}\text { SECTION } 5 . \\
\text { Data }\end{array}$ & $\begin{array}{l}\text { Move } 7 \text {. Presentation of the numerical data obtained during the } \\
\text { procedure. }\end{array}$ \\
\hline & & $\begin{array}{l}\text { SECTION } 6 . \\
\text { Results }\end{array}$ & $\begin{array}{l}\text { Move 8. Description of the development of the formulaic and data } \\
\text { manipulation. }\end{array}$ \\
\hline & & $\begin{array}{l}\text { SECTION 7. Discussion/ } \\
\text { Analysis }\end{array}$ & $\begin{array}{l}\text { Move 9. Description of the experiment results and comparison with } \\
\text { the previous hypothesis. }\end{array}$ \\
\hline & & SECTION 8. Conclusions & $\begin{array}{l}\text { Move } 10 \text {. Description of the meaning of the experiment developed. } \\
\text { Move } 11 \text {. Presentation of the implications and projections of the } \\
\text { results obtained within the experiment. }\end{array}$ \\
\hline & & $\begin{array}{l}\text { SECTION } 9 . \\
\text { References }\end{array}$ & $\begin{array}{l}\text { Move 12. Citation of all the published sources consulted during the } \\
\text { conduct of the experiment and the preparation of the laboratory } \\
\text { report }\end{array}$ \\
\hline $\begin{array}{l}\text { 2. DISCOURSE } \\
\text { LEVEL }\end{array}$ & $\begin{array}{l}\text { Cohesion and coherence } \\
\text { elements. }\end{array}$ & \multicolumn{2}{|c|}{$\begin{array}{l}\text { Discourse markers and linking words: temporal enumeration, addition and reinforcement, apposition, } \\
\text { consequence, deduction and contrast. }\end{array}$} \\
\hline $\begin{array}{l}4 . \quad \text { MORPHO- } \\
\text { SINTACTIC } \\
\text { LEVEL }\end{array}$ & \multicolumn{3}{|c|}{$\begin{array}{l}\text { - Nominalization } \\
\text { - Long nominal sentences } \\
\text { - Verb tenses (present simple) } \\
\text { - Impersonal forms (passive voice) }\end{array}$} \\
\hline $\begin{array}{l}3 . \quad \text { LEXICO- } \\
\text { SEMANTIC } \\
\text { LEVEL. }\end{array}$ & \multicolumn{3}{|c|}{$\begin{array}{l}\text { - Technicisms } \\
\text { - Neologisms } \\
\text { - Word formation (composition and derivation) } \\
\text { - Abbreviations and acronyms } \\
\text { - Extra-linguistic elements (formulae, graphs, tables...). }\end{array}$} \\
\hline
\end{tabular}

Table 2. Examples taken from the reports at a textual level

\begin{tabular}{|c|c|c|c|}
\hline \multicolumn{4}{|c|}{ 1. Textual level (macrostructure) } \\
\hline \multirow{3}{*}{ R1 } & SECTION 1. Report information & \multicolumn{2}{|l|}{ Move 1: Presentation of the author's name and title. } \\
\hline & SECTION 2. [INTRODUCTION] & \multicolumn{2}{|c|}{$\begin{array}{l}\text { Move 2: Explanation /definition of the precipitation reactions phenomenon. } \\
\text { Move 3: Citation of the reasons for the precipitation phenomenon. } \\
\text { Move 4: Explanation of the information needed to find out when reactions of precipitation take place. } \\
\text { Move 5: Presentation of solubility rules (equations). }\end{array}$} \\
\hline & $\begin{array}{l}\text { SECTION 3. [METHODS AND } \\
\text { PROCEDURE] }\end{array}$ & \multicolumn{2}{|c|}{$\begin{array}{l}\text { Move 6: Description of the steps followed to develop part } 1 \text { of the experiment (Determination of } \\
\text { silver Ions). } \\
\text { Move } 7 \text {. Description of the steps followed to develop part } 2 \text { of the experiment (Determination ofthe } \\
\text { concentration of chloride anion by precipitation titration). }\end{array}$} \\
\hline \multirow{5}{*}{ R2 } & SECTION 1.Report information. & \multicolumn{2}{|l|}{ Move 1: Presentation of the authors' names and title. } \\
\hline & SECTION 2. [INTRODUCTION] & \multicolumn{2}{|c|}{$\begin{array}{l}\text { Move 2: Explanation of the reasons for measuring the } \mathrm{Ph} \text { in water. } \\
\text { Move 3: Definition of Ph. } \\
\text { Move 4: Explanation of water hardness (close relationship with water } \mathrm{Ph} \text { ). } \\
\text { Move 5: Explanation of the reasons for measuring conductivity and salinity in water. }\end{array}$} \\
\hline & \multirow{3}{*}{$\begin{array}{l}\text { SECTION } \quad 3 . \quad[\text { METHODS, } \\
\text { MATERIALS, PROCEDURE, DATA } \\
\text { AND RESULTS] }\end{array}$} & $\begin{array}{l}\text { Move 6. Materials, procedures, data and results of } \\
\text { measuring Ph, conductivity, total salinity and osmotic } \\
\text { pressure. }\end{array}$ & $\begin{array}{l}\text { Submove 6.1. Materials and products } \\
\text { Submove 6.2. Procedure } \\
\text { Submove 6.3. Results }\end{array}$ \\
\hline & & $\begin{array}{l}\text { Move 7.Materials, procedures, data and results of } \\
\text { determining the hardness of water. }\end{array}$ & $\begin{array}{l}\text { Submove 7.1. Materials and products. } \\
\text { Submove 7.2. Procedure } \\
\text { Submove 7.3. Data } \\
\text { Submove 7.4. Results }\end{array}$ \\
\hline & & Move 8.Assessment of carbonates and bicarbonates. & $\begin{array}{l}\text { Submove 8.1. Data } \\
\text { Submove 8.2. Procedure } \\
\text { Submove 8.3. Results }\end{array}$ \\
\hline \multirow{6}{*}{ R3 } & SECTION 1.Title page. & \multicolumn{2}{|c|}{ Move 1.Presentation of the title, author's name and date of the experiment. } \\
\hline & SECTION 2. Content Index & \multicolumn{2}{|l|}{ Move 2: Numerical citation of the report contents. } \\
\hline & SECTION 3. [INTRODUCTION] & \multicolumn{2}{|c|}{$\begin{array}{l}\text { Move 3: Explanation of the meaning of redox titration. } \\
\text { Move 4: Definition of Oxidizer agent. } \\
\text { Move 5.Definition of reducing agent. } \\
\text { Move 6.Presentation of the problem or question to be solved in the laboratory. } \\
\text { Move 7: Presentation of objectives of the experiment. }\end{array}$} \\
\hline & $\begin{array}{l}\text { SECTION 4. [MATERIALS, DATA } \\
\text { AND PROCEDURE] }\end{array}$ & \multicolumn{2}{|c|}{$\begin{array}{l}\text { Move 8: Presentation of data (equations) and definition of variables. } \\
\text { Move 9: Explanation of the materials and procedure of phase } 1 \text { of the experiment. } \\
\text { Move 10: Explanation of the materials and procedure of phase } 2 \text { of the experiment. }\end{array}$} \\
\hline & SECTION 5. [RESULTS] & \multicolumn{2}{|c|}{ Move 11: Explanation of the calculations developed to solve the experiment. } \\
\hline & $\begin{array}{l}\text { SECTION } 6 . \quad \text { [CLARIFYING } \\
\text { QUESTION] [Appendix] }\end{array}$ & \multicolumn{2}{|c|}{ Move 12: Explanation of the reasons for using certain procedure during the experiment. } \\
\hline
\end{tabular}




\subsection{Textual Level}

At a textual level (macrostructure), R1 did not match with the standard sections included in the checklist, whereas in R2 the essential sections of a lab report are included, although not structured in the same way as in the checklist. R3 Closely matched the sections of the lab report described in the checklist, and it even included complementary sections, such as a content index section and a clarifying question section.

Examples from the three reports regarding this level can be found in Table 2 .

\subsection{Discourse Level}

At a discourse level, R1 shows an Excessive use of coordinate sentences and correlation between paragraphs with no markers, whereas R2 contains some different discourse markers (apposition, additive, temporal or sequential). In contrast, in R3 there is an abundance of discourse markers (exemplifying, apposition, additive, temporal or sequential, contrast and deduction).

Examples from the three reports regarding this level can be found in Table 3 .

Table 3. Examples taken from the reports at a discourse level

\begin{tabular}{|c|c|}
\hline \multicolumn{2}{|r|}{ 2. Discourse level } \\
\hline R1 & ("After preparation of..”; “Furthermore, washing the burette with distilled water and...”.) \\
\hline R2 & $\begin{array}{l}\text { (“Furthermore”, "In addition”, etc.). (“Sometimes, the reason is because...”, "In the case of conductivity..."; "On the other hand, the Ph } \\
\text { determines..."). }\end{array}$ \\
\hline R3 & $\begin{array}{l}\text { (“Oxygen is the prime example of an oxidizing agent”). (“On the other hand, a reducing agent is the element...") ("First, we have prepared } \\
\text { the solutions of potassium, (...). Second, we have prepared the solutions of oxalate. (...). Third, we have titrated the permanganate solution } \\
\text { (...). Finally we have written..."; "The first step will be (...). And now (...)”;“'Once we know the...”). } \\
\text { ("This means that...”), (“But how can [we] know...”) (“Otherwise the magnates will oxidate...”). }\end{array}$ \\
\hline
\end{tabular}

\subsection{Morpho-syntactic Level}

At a morpho-syntactic level, in R1 there is abundant use of nominalization, use of present simple and abundant use of instructional language (imperative). In R2, there is a rich use of nominalization, long nominal sentences, impersonal language, use of present simple, use of passive voice and subordinated sentences. Finally, in R3, there is also abundant use of nominalization, long nominal sentences, impersonal language, use of present simple and present perfect, rich use of passive voice and complex subordinated sentences.

Examples from the three reports regarding this level can be found in Table 4 .

Table 4. Examples taken from the reports at a morpho-syntactic level

\begin{tabular}{|c|c|}
\hline \multicolumn{2}{|r|}{ 3. Morpho-syntactic level } \\
\hline R1 & $\begin{array}{l}\text { (by action of..., formation of...) (“Appearance of a faint orange-red precipitate”; "Erlenmeyer rotation motion...”), (“A precipitation } \\
\text { reaction occur[s] when...”), (“filter the precipitate...”, "add more water...”, "divide the filtrate...”), (“Information is needed..., (...) an } \\
\text { ionic solid is called...”). }\end{array}$ \\
\hline $\mathbf{R} 2$ & $\begin{array}{l}\text { (“availability of...”, “constituent...”, "conductance of”...), (“sodium-calcon indicator”; “solid-NET indicator”...), (“And because } \\
\text { conductivity in water is affected by (...), one can detect significant changes...”; “The reason is because you can use...”), (“... we elude } \\
\text { with HCl”; "We continue throwing HCl...”), (“Information is needed...", “(...) an ionic solid is called...”), (“One can (...) detect } \\
\text { significant changes in conductivity, which is in turn an indicator of...”; “The reason behind measuring the content in water of Ca++ and } \\
\text { Mg++ is because one can determine the hardness of water, which do[es] not pose any health risk...”). }\end{array}$ \\
\hline R3 & 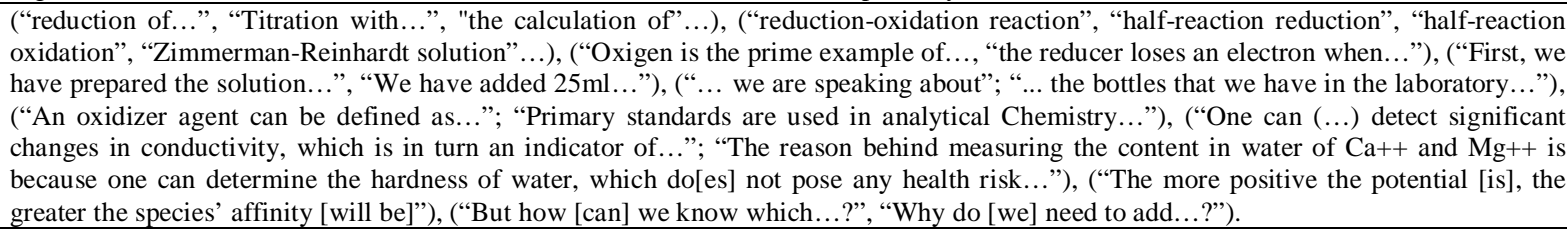 \\
\hline
\end{tabular}

\subsection{Lexico-semantic Level}

At a lexico-semantic level, R1 contains several technicisms, some compound nouns, high amount of abbreviations as well as figures, tables and graphs. R2 show an abundant use of technicisms, compound and derivate words, abbreviations and acronyms and contains formulae, figures, tables and graphs. Finally, R3 also shows a high abundance of technicisms, compound and derivate words, abbreviations and acronyms and formulae, figures, tables and graphs.

Examples from the three reports regarding this level can be found in Table 5 .

Table 5. Examples taken from the reports at a lexico-semantic level 4. Lexico-semantic level

\begin{tabular}{|l|l|}
\hline \multicolumn{2}{|c|}{ 4. Lexico-semantic level } \\
\hline R1 & $\begin{array}{l}\text { (Cations, Chloride, Ions, iodide...), (test tube, test solution, silver ions...), (reagent, supersaturation, insoluble...), (“Slowly add the } \\
\text { contents...”; “Stirring constantly in the Erlenmeyer...”), (ml, gr, H2O, mmHg...), (Kps = [A]m [Bm]n...). }\end{array}$ \\
\hline R2 & $\begin{array}{l}\text { (Osmotic, complexometric, salinity etc.), (Ph meter, conductivity meter, calcon indicator...), (discharge; insoluble..., generally...), } \\
\text { (mmHg, Ca++, Mg++...) and acronyms (EDTA, NET...), (CO3 -> HCO3-> H2CO3 -> CO2 + H2O). }\end{array}$ \\
\hline R3 & $\begin{array}{l}\text { (oxalate, Permanganate, titration, burete,millivolts, moles, quotient,etc,), } \\
\text { (oxidizer agent, conductivity meter, electron donor...), (reducer, oxidizer, subcalculation...), (mL,g,mV), (5Fe2 + Mn04 + 8H -> 5Fe3 } \\
+\mathrm{Mn}+4 \mathrm{H} 2 \mathrm{O}) .\end{array}$ \\
\hline
\end{tabular}

\section{Discussion}

The analysis of these three reports reveals noticeable differences in the writing performance of the students under study. It is evident that the main differences have to do with the textual and meta-discourse level. Whereas R1 does not match with the standard elements a lab report usually contain and are included in the lab report genre checklist, R2 is much richer from a textual and discourse 
perspective. As for R3 it can be stated that this is the one which more closely matches the ideal lab report described in the guiding checklist.

Regarding the discourse level, it is evident the difference in the use of discourse markers from R1 to R3. Whereas R1 is characterized by a scarce use of discourse markers and an excessive use of coordinate sentences which strongly difficult the reading of the document, R2 and, especially, R3, are characterized by the richness of discourse markers which favours the cohesion and coherence of the text.

As for the morpho-syntactic level, R2 and R3 show a similar use of the conventional morpho-syntactic elements included in the lab report checklist (nominalization, long nominal sentences, use of verb tenses and impersonal forms). This does not occur in R1, in which a high predominance of instructional language (the use of imperatives at the beginning of each sentence dominates the whole text) in the methods and procedure section, which denotes a total absence of knowledge on the purpose of the writing of the lab report genre as well as its communicative function.

Fewer differences have been found at the lexicosemantic level. The three reports contain, to a lesser or greater extent, almost all the elements included in the lab report checklist (technicisms, word formation, abbreviations and acronyms and extra linguistic elements). This may be due to the fact that these aspects of scientific English may have been previously studied in class.

From these results, a relationship between the students' academic performance (content achievement) and their linguistic awareness of the genre produced in a second language can be observed. The higher-marked reports (R1 and R2) show a better writing (language) performance, especially at a textual and discourse level. Regarding the morpho-syntactic and lexico-semantic level, fewer differences are found between higher and lower-marked reports (R1, R2 and R3).

\section{Conclusions}

The present paper shows the results of an experience in a CLIL higher education setting in which the written production of a specific textual genre. Results support the hypothesis of this study by which the introduction of genre awareness clearly helps improve the students' writing skills at this educational stage [9]. In fact, it has been observed how the most differences regarding a higher and a lower marked written production have to do with textual (macrostructure) and discourse issues. The concept of CLIL in higher education involves a dual focus on subject content and foreign language, as stated by [3]. Nonetheless, language needs to be understood as text and discourse, that is, the use of language beyond the sentence [12]. Results evidence that the progressive introduction of the lab report genre awareness may imply an improvement in students' written production, especially at a textual and meta discourse level, which were probably the aspects less previously practiced in their Chemistry lessons.

This experience helped the lecturers of the course under study have a widen idea for the assessment of written productions in their discipline since they could define the textual and linguistic elements to take into account, which was stated to pose a major problem for them.

The results of this study reveal that further focus would be necessary to be paid on the pedagogical approach based on textual genres for university students in order to acquire a higher level of written communicative competence.

A limitation of the present study was the small sample of analysis. The size of the sample limits the generalizability of this study. However, this study may serve as a starting point for further research that may result in future improvements in pedagogical strategies and policies to be implemented in higher education CLIL syllabus related to the inclusion of genre awareness in different academic contexts.

\section{References}

[1] Dalton-Puffer and Smit, eds. (2007). Empirical Perspectives on CLIL Classroom Discourse. Franktfurt, Vienna etc.: Peter Lang

[2] Lasagabaster, D. and Y. Ruiz de Zarobe (Ed.) (2010).CLIL in Spain.Implementation, Results and Teacher Training.Cambridge Scholars Publishing. Newcastle.

[3] Maljers, A., Marsh, D., Wolff, D., Genesee, F., Frigols-Martín, M., Mehisto, P., based on Marsh, D. \& Wolff, D. eds. (2007) Windows on CLIL: Content and Language Integrated Learning in the European Spotlight. The Hague: European Platform for Dutch Education, and Graz: European Centre for Modern Languages.

[4] Doiz, A., Lasagabaster, D. and Sierra, J.M. (eds) (2013). EnglishMedium Instruction at Universities: Global Challenges. British Library.

[5] Lorenzo, F. (2010) Lingüística de la comunicación. El currículo multilingüe de géneros textuales. Revista Signos. 43 (74) 391-410.

[6] Swales, J.M. (1990) Genre Analysis: English in Academic and Research Settings. Cambridge: Cambridge University Press.

[7] Bajtín, M. (1982) El Problema de los Géneros Discursivos. Estética de la Creación Verbal. Mexico. S. XXI, pp. 248-293.

[8] Bhatia, V. (1997) Introduction: Genre analysis and world Englishes. World Englishes 16, pp. 313-19.

[9] Eckert, P. (2006) Communities of Practices. Encyclopedia of language and linguistics. Elsevier, pp. 1-4.

[10] Hyland, K. (2004) Genre and Second Language Writing. Ann Arbor: Michigan University Press.

[11] Hyland, K. (2005) Metadiscourse. London: Continuum.

[12] Muñoz Luna, R. (2011) A Multidimensional Analysis of Academic Writing in EFL by university students: Linguistic and Extra-Linguistic variables. SPICUM Publications service. University of Malaga.

[13] Alcaraz, E. (2000) El ingles profesional y académico. Madrid: Alianza.

[14] Fernández, F. and Gil, M. (2000). Enlaces oracionales y organización retórica del discurso científico en inglés y en español. Studies in English Language and Linguistics. Universidad de Valencia.

[15] Halliday, M. (1976) Cohesion in English, London: Longman.

[16] Sager, J., Dungworth, D. and McDonald, P. (1980) English Special Languages: Principles and practice in science and technology. Wiesbaden, Brandstetter. 